https://doi.org/10.18778/1509-877X.2019.02.02

Artykuły

Ireneusz Nowak*

\title{
FUNKCJONARIUSZE CELNI W STRUKTURZE Krajowej Administracji Skarbowej \\ - UWAGI WYBRANE
}

Streszczenie. Artykuł w głównej mierze poświęcony jest problematyce tzw. ucywilnień funkcjonariuszy celnych, czyli przekształceń ich stosunków służbowych w stosunki pracy w ramach konsolidacji administracji podatkowej, skarbowej i celnej w Krajową Administrację Skarbową. Autor wykazał, że reforma administracji danin publicznych - bez wątpienia konieczna po blisko trzydziestu latach status quo - doprowadziła jednak do kilkutysięcznej redukcji w zatrudnieniu funkcjonariuszy celnych poprzez wygaszenie stosunków służbowych lub przekształcenie ich w stosunki pracy. Wskazuje ponadto, że w wyniku świadomego działania prawodawcy doszło do uchwalenia „niegodziwego prawa", będącego naruszeniem zasady zaufania do państwa i stanowionego przez nie prawa.

Słowa kluczowe: Krajowa Administracja Skarbowa, funkcjonariusz celny, stosunek służbowy, stosunek pracy, administracja danin publicznych

1. WPROWADZENIE

Punktem wyjścia dla całego opracowania jest analiza procesu legislacyjnego związanego z utworzeniem i organizacją Krajowej Administracji Skarbowej w zestawieniu z założeniami, jakie przyświecały ustawodawcy przy jej wprowadzaniu. W tym też celu przedmiot badań został wzbogacony informacjami pochodzącymi od Ministra Finansów oraz Najwyższej Izby Kontroli.

* Doktor nauk prawnych, adiunkt, Katedra Prawa Podatkowego, Wydział Prawa i Administracji, Uniwersytet Łódzki, e-mail: inowak@wpia.uni.lodz.pl, https://orcid.org/ 0000-0002-7997-6887. 
Zasadniczym założeniem badawczym artykułu jest dokonanie ustaleń dotyczących wybranych mankamentów procesu ustawodawczego związanego z konsolidacją administracji podatkowej, skarbowej i celnej w ramy Krajowej Administracji Skarbowej ze szczególnym uwzględnieniem sytuacji prawnej funkcjonariuszy celnych. Podjęte w publikacji rozważania uzasadniają postawienie tezy, zgodnie z którą przeprowadzony z inicjatywy poselskiej - a nie rządowej - proces legislacyjny, sprowadzający się do prostej reguły większościowej w parlamencie ${ }^{1}$, doprowadził w następstwie m.in. do kilkutysięcznej redukcji zatrudnienia funkcjonariuszy celnych poprzez wygaszenie im stosunku służby lub przekształcenie stosunku służby w stosunek pracy (tzw. ucywilnienie). Doszło zatem do uchwalenia „niegodziwego prawa”, będącego zaprzeczeniem poszanowania godności każdego człowieka ${ }^{2}$, nie wspominając już o ludzkich dramatach (zawodowych i rodzinnych) $)^{3}$.

2. Krajowa Administracja Skarbowa - Zarys LEGISLACYJNO-ORGANIZACYJNY

$\mathrm{Z}$ dniem 1 marca 2017 r. na podstawie ustawy z dnia 16 listopada 2016 r. o Krajowej Administracji Skarbowej ${ }^{4}$ oraz ustawy z dnia 16 listopada 2016 r. - Przepisy wprowadzające ustawę o Krajowej Administracji Skarbowej ${ }^{5}$ zaczęła funkcjonować Krajowa Administracja Skarbowa ${ }^{6}$.

1 Szerzej W. Łączkowski, Wymiar sprawiedliwości a stosowanie prawa, [w:] Ius et lex. Księga pamiątkowa ku czci prof. Adama Strzembosza, red. A. Dębiński, A. Grześkowiak, K. Wiak, Lublin 2002, s. 49 i n.

2 Szerzej W. Łączkowski, O godziwe prawo, „Ethos” 2002, nr 1-2, s. 208; M. Giełda, Godność człowieka w otoczeniu administracji publicznej - wybrane zagadnienia, „Przegląd Prawa i Administracji” 2017, nr 111, s. 45 i n.

3 Zob. W. Łączkowski, Prawo naturalne a prawo stanowione. Uwagi prawnika, „Ethos” 1999, nr 1-2, s. 173-182.

4 Tekst jedn. Dz.U. z 2020 r., poz. 505 ze zm., dalej: u.KAS.

${ }^{5}$ Dz.U. z 2016 r., poz. 1948 ze zm., dalej: p.w.KAS.

6 Szerzej I. Nowak, National Revenue Administration - current organisational and financial problems, „Prawo Budżetowe Państwa i Samorządu” 2020, nr 2, s. 37-65; idem, Krajowa Administracja Skarbowa w liczbach, „Kazus Podatkowy” 2020, nr 4, s. 24-25; pismo Ministra Finansów z dnia 23 kwietnia 2018 r., nr DOW6.054.8.2018.KZM, http://orka2. sejm.gov.pl/INT8.nsf/klucz/658C47F2/\%24FILE/i20954-o1.pdf (dostęp: 30.10.2020); pismo Ministra Rozwoju i Finansów z dnia 7 lutego 2017 r., nr RS6.054.3.2017, http://orka2. sejm.gov.pl/INT8.nsf/klucz/658C47EE/\%24FILE/i09407-o1.pdf (dostęp: 30.10.2020). 
W nowo utworzonej strukturze organizacyjnej administracji danin publicznoprawnych skonsolidowano administrację podatkową, służbę celną i kontrolę skarbową w „jedną formację"”. W rezultacie obecnie w Krajowej Administracji Skarbowej funkcjonuje:

a) 16 izb administracji skarbowej (IAS), które powstały w drodze połączenia „procesów obsługowych” realizowanych pierwotnie w izbach skarbowych, izbach celnych oraz urzędach kontroli skarbowej;

b) 16 urzędów celno-skarbowych wraz z 45 delegaturami urzędów celno-skarbowych i 143 oddziałami celnymi, w ramach których nastąpiło zintegrowanie zadań kontrolnych wykonywanych poprzednio przez urzędy kontroli skarbowej i urzędy celne;

c) 400 urzędów skarbowych (w tym 20 wyspecjalizowanych obsługujących kluczowych podatników $)^{8}$.

Generalnie nie powinno być sporu co do faktu, że struktura organizacyjna administracji danin publicznych sprzed 1 marca 2017 r., funkcjonująca bez większych modyfikacji od ponad trzydziestu lat, wymagała dostosowania jej do zmieniających się realiów społeczno-gospodarczych ${ }^{9}$, m.in. ze względu na stopień skomplikowania przepisów prawa podatkowego oraz „rosnącą finezję operacji gospodarczych i finansowych mających na celu unikanie opodatkowania”"10. Jak trafnie wskazuje J. Kulicki, „po przywróceniu do życia urzędów i izb skarbowych w 1983 r. oraz wyodrębnieniu kontroli skarbowej w 1992 r., biorąc pod uwage projekty rządowe, tylko

7 D. Gajewski, A. Nowak-Far, Krajowa Administracja Skarbowa - propozycja konsolidacji aparatu skarbowego a uszczelnienie systemu podatkowego, „Analizy i Studia” 2016, nr 2, s. 1-9; M. Laszuk, Status prawny Stużby Celno-Skarbowej, „Przegląd Prawa Publicznego" 2018, nr 6, s. 129 i n.

8 Szerzej L. Bielecki, Ustrojowe prawo administracyjne (podatkowe) dotyczace Krajowej Administracji Skarbowej jako przykład wpływu ideologii politycznej na kształt prawa, „Przegląd Prawa Publicznego” 2017, nr 7-8, s. 44 i n.; W. Byrzykowski, A. Zdunek, Ustawa o Krajowej Administracji Skarbowej - organy, zadania oraz forma ich realizacji, „Przegląd Podatkowy” 2017, nr 3, s. 47 i n.; Ustawa o Krajowej Administracji Skarbowej. Komentarz, red. L. Bielecki, A. Gorgol, Warszawa 2018; Krajowa Administracja Skarbowa. Komentarz, red. A. Melezini, K. Teszner, Warszawa 2018.

9 B. Brzeziński, Prawo podatkowe. Zagadnienia teorii i praktyki, Toruń 2017, s. 183 i n.; I. Nowak, M. Dominiak, Krajowa Administracja Skarbowa a uszczelnianie systemu podatkowego - spostrzeżenia po dwóch latach funkcjonowania, [w:] Przestępczość gospodarcza. System zwalczania. Cz. I, red. P. Łabuz, I. Malinowska, M. Michalski, Warszawa 2020, s. 111-125.

10 B. Brzeziński, W. Nykiel, Stan prawa podatkowego w Polsce. Raport 2010, „Kwartalnik Prawa Podatkowego" 2011, nr 1, s. 61 i n. 
dwukrotnie dostrzegano potrzebę kompleksowych zmian całego aparatu skarbowego podległego Ministrowi Finansów. Miało to miejsce pod koniec lat 90. XX w. i w latach 2005-2007"11. Co do zasady analogicznie czytamy w uzasadnieniu projektu ustawy o Krajowej Administracji Skarbowej, że w stanie prawnym do dnia 1 marca 2017 r. administracja danin publicznych, zajmująca się m.in. gromadzeniem dochodów budżetowych w ramach administracji rządowej, posiadała rozproszoną strukturę terenową, skupioną $\mathrm{w}$ trzech niezależnie funkcjonujących pionach: administracja podatkowa (16 izb skarbowych oraz 400 urzędów skarbowych), Służba Celna (16 izb celnych, 45 urzędów celnych wraz ze 141 oddziałami celnymi) i kontrola skarbowa (16 urzędów kontroli skarbowej) ${ }^{12}$. Co więcej, wszystkie wyżej wymienione jednostki sektora finansów publicznych na poziomie regionalnym posiadały własne budżety, kadry, majątek (ruchomy i nieruchomy ${ }^{13}$ ), opracowywały odrębne kierunki rozwoju i cele strategiczne wraz z miernikami ich realizacji ${ }^{14}$. Ponadto $\mathrm{z}$ uzasadnienia projektu ustawy o Krajowej Administracji Skarbowej wynika m.in., że wskutek niejednolitości struktur organizacyjnych, rozproszonych baz danych, powielania kompetencji czy też konkurencyjności podejmowanych działań powstała konieczność reformy i skonsolidowania aparatu danin publicznych. Głównymi zaś celami projektowanych przepisów było co do zasady obniżenie kosztów funkcjonowania administracji skarbowej w relacji do poziomu uzyskiwanych dochodów budżetowych, ograniczenie skali oszustw podatkowych m.in. poprzez zwiększenie skuteczności poboru należności podatkowych i celnych, a na rozwoju profesjonalnej kadry i zwiększeniu poziomu dobrowolności wypełniania obowiązków podatkowych kończąc $c^{15}$.

11 J. Kulicki, Koncepcja Krajowej Administracji Skarbowej w świetle problemów administracji danin publicznych $w$ Polsce, „Analizy i Studia” 2016, nr 2, s. 10 i n.; K. Teszner, Administracja podatkowa i kontrola skarbowa w Polsce, LEX/el. 2012; System organów podatkowych w Polsce, red. P. Smoleń, Warszawa 2009.

12 Uzasadnienie projektu ustawy o Krajowej Administracji Skarbowej, druk sejmowy nr 826/VIII kadencja, https://www.sejm.gov.pl/Sejm8.nsf/druk.xsp?nr=826 (dostęp: 19.09.2020), dalej: uzasadnienie KAS.

13 Administracja skarbowa i celna korzystała z 892 budynków w trwałym zarządzie o łącznej powierzchni całkowitej $1342871 \mathrm{~m}^{2}$ i 152 budynków wynajmowanych (biurowce) o łącznej powierzchni całkowitej $89659 \mathrm{~m}^{2}$ (uzasadnienie KAS).

14 Łącznie wszystkie podległe lub nadzorowane przez Ministra Finansów jednostki dysponowały budżetem przekraczającym 5,4 mld zł i zatrudniały ponad 65 tys. pracowników (uzasadnienie KAS).

15 Ibidem. 
Generalnie kierunek proponowanych i przywołanych powyżej głównych rozwiązań ustawodawczych można uznać za prawidłowy. Jednakże nie sposób zaaprobować formy ustawodawczej i trybu, w jakim konsolidowano administrację podatkową, skarbową i celną. Projekty ustaw pochodziły od grupy posłów partii mającej większość parlamentarną, $\mathrm{w}$ wyniku czego tempo ich procedowania było błyskawiczne ${ }^{16}$. Był to z pewnością celowy zabieg, ponieważ projekty poselskie nie muszą przechodzić kompleksowego procesu uzgodnień zarówno w ramach rządu, jak i ze strony interesariuszy (konsultacji społecznych i publicznych). A co więcej, projekty ustaw w tej sytuacji nie musiały być zaopatrzone w szczegółową ocenę skutków regulacji (OSR), przez co obarczone były licznymi błędami, o czym poniżej ${ }^{17}$. Jednakże de facto prace nad projektami aktów prawnych reformujących administrację finansową powstały w Ministerstwie Finansów, na co wskazuje fakt, że w styczniu 2016 r. Minister Finansów poinformował Szefową Kancelarii Prezesa Rady Ministrów o planowanym przedłożeniu Radzie Ministrów projektu ustawy o Krajowej Administracji Skarbowej, a następnie zarządzeniem z dnia 4 stycznia 2016 r. powołał zespół do opracowania projektów wyżej wymienionych regulacji prawnych ${ }^{18}$.

Biorąc pod uwagę podjęte działania legislacyjne, prawdziwy niepokój budzi fakt, że już 3 czerwca 2016 r. z inicjatywy grupy posłów wpłynęły do Sejmu wskazane wyżej projekty ustaw zawierające regulacje prawne

16 Projekty wpłynęły do Sejmu 3 czerwca 2016 r., 16 listopada 2016 r. były już uchwalone, a 2 grudnia 2016 r. zostały ogłoszone w Dzienniku Ustaw Rzeczypospolitej Polskiej pod pozycjami 1947 i 1948. Tempo iście stachanowskie (sic!).

17 Jakość procesu stanowienia prawa $w$ drugim roku rządów Prawa i Sprawiedliwości, X Komunikat Obywatelskiego Forum Legislacji o jakości procesu legislacyjnego na podstawie obserwacji w okresie od 16 listopada 2016 do 15 listopada 2017 roku, s. 22, http:// obserwatoriumdemokracji.pl/wp-content/uploads/2016/03/Komunikat-w\%C5\%82a \%C5\%9Bciwy.pdf (dostęp: 15.09.2020).

18 Od marca 2016 r. prace związane z reformą Krajowej Administracji Skarbowej kontynuowane były przez nowo utworzony Departament Reformy Administracji Skarbowej, do zadań którego należało m.in. opracowanie projektu ustawy o Krajowej Administracji Skarbowej i projektu regulacji prawnych służących wdrożeniu tej ustawy. W okresie od 23 lutego do 3 czerwca 2016 r. w Departamencie Reformy Administracji Skarbowej trwały prace nad doprecyzowaniem rozwiązań zawartych we wstępnym projekcie tej ustawy oraz opracowaniem projektu ustawy Przepisy wprowadzające ustawę o KAS (informacja Najwyższej Izby Kontroli z dnia 17 grudnia 2019 r. pt. Stan organizacji Krajowej Administracji Skarbowej, nr ewid. 159/2019/P/18/009/KBF, s. 32, https://www.nik.gov.pl/ plik/id,21676,vp,24326.pdf (dostęp: 14.08.2020), dalej: Informacja NIK). 
uwzględniające rozwiązania wypracowane w Ministerstwie Finansów, gdzie jednocześnie zaniechano ich kontynuowania ${ }^{19}$. Jak zauważa Najwyższa Izba Kontroli, „przedłożone przez posłów projekty zawierały regulacje, które uwzględniały rozwiązania wypracowane $\mathrm{w}$ ramach prac prowadzonych $\mathrm{w}$ Ministerstwie Finansów, jak również wyniki analizy stenogramów z posiedzeń sejmowej Komisji Finansów Publicznych, z pierwszego czytania projektu ustawy na posiedzeniu plenarnym Sejmu oraz nagrań z posiedzeń podkomisji powołanej do rozpatrzenia obu projektów, z których wynika, że to przedstawiciele Ministerstwa Finansów, a nie autorzy projektów, odegrali dominującą rolę w zakresie uzasadniania projektowanych zmian oraz odpowiedzi na pytania i wątpliwości posłów opozycji i zaproszonych gości”20.

Podsumowując przedstawione powyżej rozważania, należy wysunąć wniosek, że „projekty obu ustaw powstały w Ministerstwie Finansów w sposób omijający gwarancyjne reguły rządowego procesu legislacyjnego określone w Regulaminie pracy Rady Ministrów, w szczególności w zakresie opracowania szczegółowej oceny skutków regulacji i przeprowadzenia konsultacji publicznych, a następnie - w sposób nieformalny - zostały przekazane posłom koalicji rządzącej w celu skorzystania przez nich z prawa inicjatywy ustawodawczej. Ten sposób działania nie odpowiada regułom państwa prawa, albowiem zaburza transparentność procesu legislacyjnego i powoduje, że Rada Ministrów wyzbywa się części odpowiedzialności za kształt systemowych reform administracji rządowej, takich jak ta dotycząca KAS”21. Innymi słowy, jednoznacznie negatywna jest praktyka pisania ustaw przez ministerstwa, a następnie przedstawiania ich jako projekty poselskie, gdyż zgodnie z tą nagminnie stosowaną w ostatnich latach „metodą” pomija się konsultacje z ekspertami, co musi doprowadzić do katastrofy prawnej, ponieważ im szybciej tworzy się prawo, tym jest ono gorsze ${ }^{22}$. Bez

19 Ibidem, s. $14 \mathrm{i} \mathrm{n.}$

${ }^{20}$ Ibidem; zob. także wypowiedzi podsekretarza stanu w Ministerstwie Finansów podczas posiedzenia Komisji Finansów Publicznych z dnia 18 listopada 2016 r., http:// orka.sejm.gov.pl/Zapisy8.nsf/wgskrnr/FPB-116 (dostęp: 10.07.2020).

${ }_{21}^{21}$ M. Szwast, Ocena przeprowadzonej reformy zwiazanej z utworzeniem Krajowej Administracji Skarbowej w świetle zasad tworzenia prawa i ochrony praw pracowniczych, 15 września 2018 r., s. 11.

${ }_{22}$ Por. K. Żaczkiewicz-Zborska, W 2018 r. więcej ustaw, ale złej jakości i pisanych w pośpiechu, https://www.prawo.pl/prawo/jakosc-prawa-tworzonego-w-polsce-w-2018roku,351131.html (dostęp: 5.08.2020). 
wątpienia jest to tzw. upolitycznienie legislacji przez większość parlamentarną (absolutyzowanie reguły większościowej) ${ }^{23}$.

W literaturze przedmiotu stwierdza się, że „ulepszać państwo mogą ludzie uwolnieni od egoizmu, egocentryzmu, nieżyczliwości i cwaniactwa oraz hochsztaplerstwa, odpowiednio wykształceni i posiadający zdolność zastosowywania osiągnięć nauki i cywilizacji, bez instrumentalnego naginania ich osiągnięć - świadomie lub nieświadomie - w praktycznym działaniu. Nadto, koniecznie potrzebni są ludzie posiadający cechy pokory myślowej i intelektualnej, szacunek do innych ludzi i do prawdy, a nie hermetycznie zamknięte umysły” ${ }^{24}$. Tym samym „o sprawnym i skutecznym działaniu administracji publicznej decyduje m.in. „oparta na racjonalistycznych założeniach stabilizacja struktur administracji publicznej. W tej kwestii sprawujący władzę powinni się wyzbyć chorobliwej maniery polegającej na psuciu, a nawet burzeniu wszystkiego, co zrobił poprzedni rząd. [...] Burzenie i tworzenie od nowa lub ciągłe poprawianie tego, co inni zbudowali (ale nie zawsze lepiej od poprzedników), to zarówno kosztowne, jak i złe pomysły” ${ }^{25}$. Niestety, obserwując „pragmatykę” polskiej legislacji - nie tylko podatkowej - w dalszym ciągu aktualne jest spostrzeżenie J. Szpotańskiego, iż „tak się historii koło kręci, że najpierw są inteligenci, co mają szczytne ideały i przeobrazić świat chcą cały, miłością płonąc do abstraktów, najbardziej nienawidzą faktów, fakty teoriom bowiem przeczą, a to jest karygodną rzeczą"26.

${ }^{23}$ W. Łączkowski, Wymiar sprawiedliwości..., s. 53; T. Biernat, Między polityką a prawem. Problem „upolitycznienia” tworzenia prawa, przegląd prawa i administracji, „Przegląd Prawa i Administracji” 2017, nr 110, s. 115 i n.

${ }^{24}$ B. Jastrzębski, Ustrojowe zasady demokratycznego państwa prawa (jako gwarancje ochrony praw obywatelskich), [w:] Prawne gwarancje ochrony praw jednostki wobec działań administracji publicznej, red. E. Ura, Rzeszów 2002, s. 201, za: E. Ura, S. Pieprzny, Reforma administracji celno-skarbowej przyczyna wygaśnięcia stosunków zatrudnienia z mocy prawa pracowników i funkcjonariuszy tej administracji, [w:] Przemiany cywilizacyjne a funkcjonowanie administracji publicznej. Ksiega jubileuszowa dedykowana Profesorowi Bronisławowi Jastrzębskiemu w dziewięćdziesiąta rocznicę urodzin, red. J. Strzelecki, Płock 2017, s. 181.

25 B. Jastrzębski, Wybrane zagadnienia sprawnego działania administracji publicznej, [w:] Administracja publiczna u progu XXI wieku. Prace dedykowane prof. zw. dr. hab. Janowi Szreniawskiemu z okazji Jubileuszu 45-lecia pracy naukowej, red. Z. Niewiadomski, J. Buczkowski, J. Łukasiewicz, J. Posłuszny, J. Stelmasiak, Przemyśl 2000, s. 229, za: E. Ura, S. Pieprzny, Reforma..., s. 229.

26 J. Szpotański, Gnom. Caryca. Szmaciak, Łomianki 2014, s. 171. 
$\mathrm{Na}$ gruncie powyższych rozważań warto również zwrócić uwagę, że prace nad projektem reformy administracji danin publicznych zmierzające do jej konsolidacji prowadzone były w Ministerstwie Finansów już w latach 2005-200727. Wówczas projekt ustawy Przepisy wprowadzające ustawę o Krajowej Administracji Skarbowej był projektem rządowym ${ }^{28}$ i został przedłożony do konsultacji partnerom społecznym zainteresowanym rozstrzygnięciami reformy, tj. związkom zawodowym pracowników służb skarbowych i celnych, organizacjom zrzeszającym pracodawców, korporacji zawodowej doradców podatkowych oraz stowarzyszeniom podatników i dziennikarzy polskich. Ponadto wszelkie propozycje oraz postulaty zgłaszane przez wskazane wyżej podmioty były rozpatrywane i uwzględnione w pracach nad projektem ${ }^{29}$.

\section{Przeksztącenie Stosunków SŁUŻBowych FUnKCJONARIUSZy} CELNYCH W STOSUNKI PRACY (TZW. UCYWILNIENIE)

Przepisy wprowadzające ustawę o Krajowej Administracji Skarbowej w artykułach 165-174 regulowały trzy rodzaje rozwiązań prawnych dotyczących zmiany stosunku służbowego dotychczasowych funkcjonariuszy Służby Celnej. Pierwszy ze sposobów można określić jako kontynuację stosunku służbowego poprzez złożenie propozycji pełnienia służby na nowych warunkach. Drugi wariant polegał na wygaśnięciu dotychczasowego stosunku służbowego, które następowało w wyniku niezłożenia funkcjonariuszowi celnemu propozycji dalszego zatrudnienia lub w przypadku niezaakceptowania przez niego propozycji zatrudnienia albo pełnienia służby w określonym przez prawo terminie ${ }^{30}$. Trzecie wreszcie rozwiązanie polegało na przekształceniu dotychczasowego stosunku służbowego w stosunek

${ }^{27}$ Ówczesny projekt ustawy Przepisy wprowadzające ustawę o Krajowej Administracji Skarbowej zakładał, że ustawa o Krajowej Administracji Skarbowej wejdzie w życie z dniem 1 lipca 2008 r., http://orka2.sejm.gov.pl/IZ5.nsf/main/56EE52DA (dostęp: 15.10.2020).

28 Pismo Ministra Finansów z dnia 2 października 2007 r., http://orka2.sejm.gov.pl/ IZ5.nsf/main/56EE52DA (dostęp: 25.09.2020).

${ }^{29}$ W. Nykiel, Opinia z 2 lipca 2007 r. o projekcie ustawy o Krajowej Administracji Skarbowej, nr RL-0303-69/07, https://radalegislacyjna.gov.pl/dokumenty/opinia-z-2-lipca2007-r-o-projekcie-ustawy-o-krajowej-administracji-skarbowej (dostęp: 12.08.2020); pismo Ministra Finansów z dnia 10 lipca 2007 r., http://orka2.sejm.gov.pl/IZ5.nsf/main/3114D8D7 (dostęp: 17.08.2020).

${ }^{30} \mathrm{~W}$ takim przypadku dochodziło do wygaśnięcia stosunku służbowego funkcjonariusza celnego, czyli zwolnienia ze służby. 
pracy na skutek złożenia funkcjonariuszowi celnemu propozycji zatrudnienia na podstawie umowy o pracę i jej przyjęcia ${ }^{31}$. Odmowa przyjęcia propozycji skutkowała wygaśnięciem stosunku służbowego. Bez wątpienia była to sui generis „propozycja nie do odrzucenia”, w rodzaju tej składanej przez Dona Corleone (głównego bohatera filmu Ojciec Chrzestny) swoim „partnerom biznesowym”. Innymi słowy, w nowej „odsłonie prawnej” podstawą zatrudnienia 4072 funkcjonariuszy celnych ${ }^{32}$ nie był już stosunek służbowy, ale umowa o pracę. Nastąpiło więc tzw. ucywilnienie ${ }^{33}$ funkcjonariuszy celnych, nolens volens skutkujące wygaśnięciem dotychczasowych stosunków służbowych ${ }^{34}$. Oznacza to, że w ramach tworzenia tzw. prawa niegodziwego, będącego następstwem oderwania prawa od moralności ${ }^{35}$, zrezygnowano ze statusu funkcjonariuszy celnych jako jedynej grupy zawodowej związanej z pracodawcą administracyjnoprawnym stosunkiem służby ${ }^{36}$.

Nie ulega wątpliwości, że w ramach reformy związanej z utworzeniem Krajowej Administracji Skarbowej ustawodawca świadomie pogorszył sytuację prawną funkcjonariuszy celnych, powodując destabilizację trwałości ich stosunków służbowych, nie wspominając już o trudnych do zaakceptowania i niekorzystnych skutkach społeczno-bytowych czy o utracie zaufania wobec prawodawcy i swojego pracodawcy kończąc ${ }^{37}$. Również dla jednostek organizacyjnych Krajowej Administracji Skarbowej taki „zabieg prawny” należy ocenić in minus, ponieważ utrudnił on

31 Uchwała Naczelnego Sądu Administracyjnego (NSA) z dnia 1 lipca 2019 r., I OPS $1 / 19$, CBOSA.

32 Informacja NIK, s. 47-51.

33 Szerzej E. Ura, „Ucywilnianie” dotychczasowych stosunków stużbowych funkcjonariuszy celnych $w$ związku z reformą administracji celno-skarbowej - w kontekście zasady praworządności, „Przegląd Prawa i Administracji” 2018, nr 114, s. 255 i n.

${ }_{34}$ Pismo Ministra Rozwoju i Finansów z kwietnia 2017 r., nr AP2.054.3.2017, http:// orka2.sejm.gov.pl/INT8.nsf/klucz/658C47EF/\%24FILE/i11106-o1.pdf (dostęp: 6.09.2020).

35 Szerzej W. Łączkowski, Prawo..., s. 178 i n.; A. Gomułowicz, Moralność podatkowa - uwarunkowania i zasadnicze dylematy, [w:] Ex iniuria non oritur ius. Ksiega pamiątkowa ku czci Profesora Wojciecha Łaczkowskiego, red. A. Gomułowicz, J. Małecki, Poznań 2003, s. 370.

36 M. Szwast, Ocena..., s. 6.

37 Opinia Sądu Najwyższego z dnia 7 lipca 2016 r., nr BSA111-021-269-270/16 o poselskich projektach ustaw o Krajowej Administracji Skarbowej oraz Przepisy wprowadzające ustawę o Krajowej Administracji Skarbowej, przedstawionych przez grupę posłów Klubu Parlamentarnego „Prawo i Sprawiedliwość”, https://www.lubelskie.pl/ file/2016/09/4e.Opinia-S\%C4\%85du-Najwy\%C5\%BCszego-o-poselskich-projketach -ustaw-o-KAS.pdf (dostęp: 4.09.2020). 
zabezpieczenie interesu budżetu państwa. Analogicznie zdaniem Rzecznika Praw Obywatelskich ${ }^{38}$ oraz organizacji zakładowych NSZZ „Solidarność" optymalnym rozwiązaniem powinno być tzw. stopniowe (ewolucyjne) „ucywilnienie”, które polegałoby na zastępowaniu funkcjonariuszy celnych pełniących służbę na stanowiskach niezwiązanych bezpośrednio z ustawowymi zadaniami formacji - pracownikami cywilnymi, na wzór „ucywilnienia” wprowadzonego np. w Policji oraz w innych służbach podległych Ministerstwu Spraw Wewnętrznych i Administracji ${ }^{39}$. Innymi słowy, tzw. etapowe obsadzanie etatów funkcjonariuszy celnych pracownikami cywilnymi pozwoliłoby na zachowanie odpowiednich proporcji pomiędzy interesem jednostki a interesem państwa ${ }^{40}$. Także według raportu Najwyższej Izby Kontroli przeprowadzony proces konsolidacyjny służby celnej obarczony był licznymi nieprawidłowościami i uchybieniami, m.in. poprzez brak ze strony Ministra Finansów kontroli w zakresie prac zespołów powołanych w izbach administracji skarbowej w celu zapewnienia prawidłowości i transparentności przedkładania propozycji pracy bądź służby w Krajowej Administracji Skarbowej ${ }^{41}$. Przykładowo nie przeprowadzono pełnej analizy potrzeb etatowych w poszczególnych jednostkach Krajowej Administracji Skarbowej w zakresie funkcjonariuszy Służby Celno-Skarbowej ${ }^{42}$. Notabene nie dokonano jej przed wejściem w życie ustaw konsolidujących, ponieważ tzw. zespoły w sprawie określenia limitu etatów dla funkcjonariuszy Służby Celno-Skarbowej

38 Zob. wniosek Rzecznika Praw Obywatelskich skierowany do Prezydenta RP o skorzystanie z prerogatywy określonej art. 122 ust. 3 Konstytucji, tj. o wystąpienie przed podpisaniem tych ustaw $\mathrm{z}$ wnioskiem do Trybunału Konstytucyjnego o zbadanie zgodności ustawy z dnia 16 listopada 2016 r. - Przepisy wprowadzające ustawę o KAS z Konstytucją, https://www.rpo.gov.pl/sites/default/files/WG\%20do\%20Prezydenta\%20 RP\%20w\%20sprawie\%20Krajowej\%20Administracji\%20Skarbowej\%2C\%201\%20 grudnia\%202016\%20r..pdf (dostęp: 10.10.2020).

39 Pismo Rzecznika Praw Obywatelskich z dnia 20 lutego 2017 r., nr WZF.053.2.2016. TO skierowane do Ministra Rozwoju i Finansów, https:/www.rpo.gov.pl/sites/default/files/ Wyst\%C4\%85pienie\%20do\%20Ministra\%20Rozwoju\%20i\%20Finans\%C3\%B3w\%20w\%20 sprawie $\% 20 \%$ E2\%80\%9Eucywilnienia\%E2\%80\%9D\%20funkcjonariuszy\%20celnych.pdf (dostęp: 11.09.2020).

${ }^{40}$ Konsolidacja służb celno-skarbowych w świetle skarg kierowanych do Rzecznika Praw Obywatelskich, https://www.rpo.gov.pl/pl/content/konsolidacji-sluzb-celnoskarbowych-w-swietle-skarg-do-rzecznika-praw-obywatelskich (dostęp: 1.09.2020).

41 Informacja NIK, s. 20.

42 Ibidem, s. 12. 
podjęły pracę dopiero 15 września 2017 r. ${ }^{43}$ Dyrektorzy izb administracji skarbowej wszczynali procedury zatrudniania nowych funkcjonariuszy celnych już od 1 marca 2017 r., tj. w sytuacji, gdy nie zakończono jeszcze procesu przedkładania/nieprzedkładania propozycji służby/pracy, pomimo że nie dysponowali informacjami o liczbie przyjętych bądź nieprzyjętych propozycji służby/pracy ${ }^{44}$. Ponadto trzymiesięczne vacatio legis oraz czas, jaki mieli kierownicy jednostek organizacyjnych Krajowej Administracji Skarbowej (w szczególności jej dyrektorzy) na przeprowadzenie analizy ich funkcjonowania w kontekście powierzonych im zadań, były niewystarczające na rzetelne przygotowanie wdrożenia reformy, w tym rozpoznanie potrzeb kadrowych ${ }^{45}$.

Przyporządkowania funkcjonariuszy celnych do poszczególnych komórek dokonywali dyrektorzy izb administracji skarbowej w ramach posiadanych zasobów kadrowych, przedkładając (lub nie) propozycje służby/pra$c y^{46}$. Jednakże zdaniem M. Piotrowskiego w praktyce, w okresie, w którym propozycje miały być składane, stworzono „nieformalny system poufnych rekomendacji (tzw. system poufnego opiniowania, pozwalający ignorować aktualne oceny okresowe i standardy oceniania w służbie publicznej)" Efekt: propozycji służby nie otrzymywały m.in. osoby zasłużone „merytorycznie” z długim stażem pracy w służbach celno-skarbowych, wśród których znaleźli się także funkcjonariusze celni wykonujący zadania w ramach grup zadaniowych, np. do spraw narkotyków, papierosów, hazardu itp. ${ }^{48}$ Co czwarty funkcjonariusz celny nie otrzymał żadnych propozycji pracy/ służby, pomimo że posiadał specjalistyczne uprawnienia, np. do obsługi urządzeń rentgenowskich (również mobilnych) czy kontroli drogowych, lub pełnił służbę w wydziałach zwalczania przestępczości ekonomicznej ${ }^{49}$. O zgrozo - według danych Ministerstwa Finansów - szacunkowe koszty wykwalifikowania 830 funkcjonariuszy Służby Celnej, którzy odeszli ze

43 Ibidem, s. 15.

${ }^{44}$ Ibidem, s. 51.

45 Ibidem, s. 20.

46 Ibidem, s. 44.

47 M. Piotrowski, Ocena przeprowadzonej reformy związanej z utworzeniem Krajowej Administracji Skarbowej w świetle zasad tworzenia prawa i ochrony praw pracowniczych, listopad 2018, s. 57.

48 Informacja NIK, s. 47 i n.

49 Ibidem, s. 50. 
służby w związku z nieotrzymaniem bądź nieprzyjęciem nowych warunków zatrudnienia/pełnienia służby, to co najmniej 6,6 mln zł ${ }^{50}$.

W celu zapewnienia płynności działań Służby Celno-Skarbowej dyrektorzy izb administracji skarbowej występowali z wnioskami o zwiększenie limitu etatów funkcjonariuszy celnych, jednakże było to możliwe tylko poprzez przekształcenie etatów „cywilnych” na etaty funkcjonariuszy w ramach ogólnego planu etatów danej jednostki organizacyjnej ${ }^{51}$. Jak zasadnie podkreślił M. Rząsa, „na przykładzie IAS w Rzeszowie można wprost powiedzieć, że ucywilnienie nie miało żadnego sensu, gdyż zaraz po tym procesie ogłoszono w niedługim czasie dwie rekrutacje na ponad 210 funkcjonariuszy. Dodatkowo należy poinformować, że rekrutacje zakończyły się niepowodzeniem ze względu na małą liczbę odpowiednich kandydatów" 52 .

Bez wątpienia wskazane powyżej „postępowania” dyrektorów izb administracji skarbowej czynione były w celu „oczyszczenia szeregów”, w tym z przedstawicieli związków zawodowych ${ }^{53}$. Żadnych problemów nie dostrzegano także - a może trafniej byłoby powiedzieć, nie chciano zauważać - w Radzie Ministrów, ponieważ jak wynika z pisma Ministra Finansów, „stan wdrażania Krajowej Administracji Skarbowej, ze szczególnym uwzględnieniem spraw pracowniczych był przedmiotem posiedzenia Rady Służby Publicznej przy Prezesie Rady Ministrów, która na posiedzeniu w dniu 4 lipca 2017 r. podjęła, bez zastrzeżeń, uchwałę o przyjęciu informacji Ministra Finansów o stanie wdrażania Krajowej Administracji Skarbowej, ze szczególnym uwzględnieniem spraw pracowniczych" ${ }^{34}$.

W nawiązaniu do prac z lat 2005-2007 konsolidujących Krajową Administrację Skarbową wypada zaznaczyć, że już wtedy w piśmiennictwie wskazywano, iż modernizacja polskiej administracji podatkowej jest nieunikniona, jednakże tzw. rozwiązania kadrowe są wadliwe, gdyż planowana reforma

50 Ibidem, s. 22, 91.

${ }^{51}$ Pismo Ministra Finansów z dnia 16 października 2019 r., nr DOS11.054.24.2019. KZM, http://orka2.sejm.gov.pl/INT8.nsf/klucz/ATTBH6GT9/\%24FILE/i33509-o1.pdf (dostęp: 26.08.2020).

${ }^{52}$ Interpelacja poselska nr 33509 do Ministra Finansów w sprawie niezrozumiałej, niezgodnej z linią orzeczniczą NSA polityki kadrowej w ramach KAS, czego konsekwencją jest m.in. nielogiczna rezygnacja z funkcjonariuszy IAS Rzeszów prowadząca do osłabienia wschodniej granicy Polski, a zarazem Unii Europejskiej, http://www.sejm.gov.pl/ sejm8.nsf/InterpelacjaTresc.xsp?key=BFVDYR\&view=6 (dostęp: 29.09.2020).

53 E. Ura, S. Pieprzny, Reforma..., s. 181.

${ }^{54}$ Pismo Ministra Finansów z października 2018 r., nr DLK1.054.102.2018, http://orka2. sejm.gov.pl/INT8.nsf/klucz/ATTB5MHHJ/\%24FILE/i26275-o1.pdf (dostęp: 11.08.2020). 
doprowadziłaby do zwolnień i redukcji pracowników bez jasnych kryteriów selekcji i swobodnego uznania w myśl tzw. opcji zerowej ${ }^{55}$. Także zdaniem Rzecznika Praw Obywatelskich, sygnalizującego ówcześnie ten problem Ministrowi Finansów, reforma spowoduje dla funkcjonariuszy celnych trudne do zaakceptowania, niekorzystne skutki społeczne, takie jak utrata pracy i rozpad więzi rodzinnych ${ }^{56}$. Pozwala to stwierdzić, że podsekretarz stanu w Ministerstwie Finansów, który - nazwijmy to umownie - był spiritus movens konsolidacji administracji danin publicznych zarówno w latach 2005-2007, jak i 2016-2017 oraz następnych, bezzasadnie zapewniał, że „nie można wyciągać daleko idących wniosków o zamiarze masowych zwolnień w administracji celnej, zwłaszcza że podjęte działania mają na celu poprawę warunków pracy i płacy osób, które będą zatrudnione w KAS, jak też stabilizację ich sytuacji zawodowej, co w istocie będzie możliwe po utworzeniu specjalistycznej służby skarbowej" ${ }^{57}$. Tym samym zaproponowana przez projektodawcę koncepcja i rozwiązania legislacyjne w zakresie konsolidacji administracji skarbowej były niestety w pełni świadomym działaniem.

\section{FunKCJONARIUSZE CELNI W LICZBACH}

Stan zatrudnienia $\mathrm{w}$ administracji danin publicznych na dzień 30 kwietnia 2016 r. - czyli prawie rok przed wejściem w życie ustawy o Krajowej Administracji Skarbowej - wynosił 67758 osób, z czego w urzędach celnych i izbach celnych było to 14987 osób $^{58}$. Z danych uzyskanych od Ministra Finansów w ramach interpelacji poselskiej na dzień 6 czerwca 2019 r. ${ }^{59}$ wynika, że:

55 Szerzej K. Teszner, Administracja podatkowa...

56 Pismo z dnia 13 czerwca 2007 r., nr RPO-551880-IX-906/07/WK, https://www. rpo.gov.pl/sites/default/files/Wystapienie\%20RPO\%20Janusza\%20Kochanowskiego\%20 z\%202007\%20r..pdf (dostęp: 19.10.2020).

57 Pismo Ministra Finansów z dnia 4 kwietnia 2007 r., http://orka2.sejm.gov.pl/IZ5. nsf/main/39998EDC (dostęp: 7.09.2020).

${ }^{58}$ W izbach i urzędach skarbowych - 45098 tys., w urzędach kontroli skarbowej - 5452 tys., w Ministerstwie Finansów - 2221 tys. - według pisma Ministra Finansów z dnia 9 czerwca 2016 r., nr BDG7.054.3.2016, http://orka2.sejm.gov.pl/INT8.nsf/ klucz/323A0944/\%24FILE/i03269-o1.pdf (dostęp: 9.07.2020).

${ }_{59}$ Pismo Ministra Finansów z dnia 6 czerwca 2019 r., nr DOW6.054.5.2019.KZM, http://www.sejm.gov.pl/sejm8.nsf/InterpelacjaTresc.xsp?key=BD4JCQ\&view=6 (dostęp: 3.07.2020). 
a) liczba funkcjonariuszy celnych z Urzędów Celnych, którym nie przedłożono nowych warunków pracy - wyniosła 436 osób;

b) liczba funkcjonariuszy celnych $\mathrm{z}$ izb celnych, którym nie przedłożono nowych warunków pracy - wyniosła 209 osób;

c) liczba funkcjonariuszy celnych, którym z dniem 1 marca 2017 r. zaproponowano inne warunki pracy, tzw. ucywilnienie - wyniosła 2845 osób;

d) liczba funkcjonariuszy celnych i pracowników, którym po dniu 1 marca 2017 r. wypłacono m.in. odprawy emerytalne, a nie zaproponowano nowych warunków pracy - wyniosła 2047 osób;

e) liczba funkcjonariuszy celnych i pracowników, którzy po dniu 1 marca 2017 r. rozwiązali stosunek pracy/służby - wyniosła 6300 osób;

f) liczba pozwów wniesionych po dniu 1 marca 2017 r. do sądów pracy przez funkcjonariuszy urzędów celnych - wyniosła 174;

g) liczba pozwów wniesionych po dniu 1 marca 2017 r. do sądów pracy przez funkcjonariuszy izb celnych - wyniosła 147;

h) liczba pozwów wniesionych po dniu 1 marca 2017 r. do sądów administracyjnych przez funkcjonariuszy urzędów celnych - wyniosła 557;

i) liczba pozwów wniesionych po dniu 1 marca 2017 r. do sądów administracyjnych przez funkcjonariuszy izb celnych - wyniosła 909;

j) liczba funkcjonariuszy nowo przyjętych do urzędów celno-skarbowych po dniu 1 marca 2017 r. - wyniosła 412 osób.

Według dyrektora Departamentu Budżetu, Logistyki i Kadr Krajowej Administracji Skarbowej obciążenie budżetu państwa z tytułu roszczeń dochodzonych w ramach cywilnych postępowań sądowych może wynosić $10 \mathrm{mln} \mathrm{z}^{60}$. Warto jednak przypomnieć, że w przepisach wprowadzających ustawę o Krajowej Administracji Skarbowej wskazywano, iż projektowana regulacja wpłynie oczywiście na wzrost wydatków sektora finansów publicznych w okresie wdrażania, a szacunkowe koszty utworzenia Krajowej Administracji Skarbowej w 2017 r. wyniosą około 4202000 zł ${ }^{61}$. No cóż, w wyniku tzw. kreatywnej polityki kadrowej zatrudnienie ogółem w jednostkach Krajowej Administracji Skarbowej nie uległo istotnej zmianie $^{62}$, a wypływy z budżetu państwa przekraczają z nawiązką zakładane wydatki.

\footnotetext{
${ }^{60}$ Informacja NIK, s. 66.

61 Uzasadnienie KAS.

${ }^{62}$ Informacja NIK, s. 47.
} 
Liczba zatrudnionych funkcjonariuszy Służby Celno-Skarbowej w podziale na poszczególne izby administracji skarbowej w Polsce wraz z podległymi urzędami celno-skarbowymi ${ }^{63}$ na dzień 31 grudnia 2019 r. wynosi $10451^{64}$, z czego w: IAS w Białymstoku - 1007; IAS w Bydgoszczy - 222; IAS w Gdańsku - 659; IAS w Katowicach - 646; IAS w Kielcach - 134; IAS w Krakowie - 423; IAS w Lublinie - 1763; IAS w Łodzi - 429; IAS w Olsztynie - 789; IAS w Opolu - 205; IAS w Poznaniu - 494; IAS w Rzeszowie - 1123; IAS w Szczecinie - 439; IAS w Warszawie - 1238; IAS we Wrocławiu - 484; IAS w Zielonej Górze - $396^{65}$.

Niepoprawne jest jednak myślenie, że nowo przyjęci do Krajowej Administracji Skarbowej po dniu 1 marca 2017 r., i co do zasady niedoświadczeni, pracownicy oraz funkcjonariusze celni w liczbie 5340 tys. ${ }^{66}$ natychmiast zastąpią fachową i wyspecjalizowaną kadrę ${ }^{67}$ (sic!). Czekamy zatem wspólnie na zapowiadane przez permanentnie zmieniających się w ostatnich latach: ministrów finansów, szefów KAS, podsekretarzy stanu, dyrektorów departamentów oraz ich zastępców - „inwestycje w kadry Krajowej Administracji Skarbowej"68.

${ }^{63} \mathrm{Z}$ wyłączeniem osób zatrudnionych na umowę zastępstwa oraz przebywających na urlopach bezpłatnych i urlopach związanych z rodzicielstwem.

${ }^{64}$ Według pisma Ministra Finansów z dnia 17 lutego 2020 r., nr BMI1.0123.188.2020.

${ }^{65}$ W komórkach organizacyjnych Krajowej Administracji Skarbowej w Ministerstwie Finansów liczba funkcjonariuszy Służby Celno-Skarbowej pełniących służbę wynosi 262 - pismo Ministra Finansów, Inwestycji i Rozwoju Warszawa z dnia 14 października 2019 r., BMI1.0124.1103.2019.

${ }^{66}$ Szerzej wraz z wyjątkami - zob. pismo Ministra Finansów z dnia 6 czerwca 2019 r., nr DOW6.054.5.2019.KZM, http://www.sejm.gov.pl/sejm8.nsf/InterpelacjaTresc. $\mathrm{xsp}$ ?key=BD4JCQ\&view=6 (dostęp: 12.09.2020).

${ }_{67}$ Zob. B. Brzeziński, Współczesne problemy organizacji i działania administracji podatkowej na świecie, „Kwartalnik Prawa Podatkowego” 2002, nr 2, s. 19; idem, Prawo..., s. 183 i n.; M. Kaliński, Rozwój zasobów ludzkich w administracji podatkowej, „Zarządzanie Zasobami Ludzkimi” 2011, nr 5, s. 49-67; I. Nowak, Krajowa Administracja Skarbowa... s. 24-25; R. Kosińska, E. Ruśkowski, P. Woltanowski, Efektywność służb podatkowych $w$ okresie ich reformowania - wybrane zagadnienia, „Finanse, Rynki Finansowe, Ubezpieczenia" 2016, nr 6, s. 17-27.

${ }^{68}$ Szerzej I. Nowak, National Revenue Administration... s. 61; pismo Ministra Rozwoju i Finansów z dnia 8 sierpnia 2017 r., nr DLK2.054.22.2017, http://orka2.sejm.gov. pl/INT8.nsf/klucz/658C47F0/\%24FILE/i14265-o1.pdf (dostęp: 17.09.2020); pismo Ministra Finansów z marca 2018 r., nr DLK2.054.11.2018, http:/orka2.sejm.gov.pl/INT8.nsf/ klucz/658C47F2/\%24FILE/i19750-o1.pdf (dostęp: 22.08.2020). 
Utworzenie Krajowej Administracji Skarbowej było największą z reform dokonanych w administracji danin publicznych na przestrzeni ostatnich kilkudziesięciu lat ${ }^{69}$. Jednakże ten „koncept” ustawodawcy nie w pełni się powiódł, ponieważ istotnym mankamentem związanym $\mathrm{z}$ utworzeniem Krajowej Administracji Skarbowej jest fakt, że ustawy łączące administrację podatkową, służbę celną i kontrolę skarbową weszły w życie za wcześnie, bez dostatecznej oceny ich skutków, ale przede wszystkim z wielkimi zawirowaniami w zakresie zatrudniania wszystkich pracowników - nie tylko funkcjonariuszy celnych ${ }^{70}$. Zapewnienia zaś ówczesnego Szefa Krajowej Administracji Skarbowej, że „jednym z najważniejszych czynników warunkujących powodzenie reformy administracji skarbowej jest stabilizacja sytuacji zawodowej i finansowej kadr KAS”71, nie można w pełni zaaprobować, gdyż - jak trafnie podnosi J. Cichoń - reformę wykorzystano do licznych „zwolnień i przeprowadzenia czystek kadrowych”, a roszady personalne wprowadziły ogromny chaos organizacyjny, powodując frustrację pracowników i funkcjonariuszy celnych, skutkując odejściem z pracy lub służby osób z ogromnym doświadczeniem ${ }^{72}$. Analogicznie wskazuje S. Siwy (przewodniczący Związku Zawodowego Celnicy PL), że „w efekcie realizacji ustawy wprowadzającej KAS zdemotywowano [...] ludzi z wysokimi kwalifikacjami i doświadczeniem oraz wieloletnim stażem, których praktycznie zrównano z nowo przyjmowanymi do służby kadrami"73. Notabene S. Siwy nie otrzymał propozycji zatrudnienia w Krajowej Administracji Skarbowej, pomimo że „kierownictwo zarówno Ministerstwa Finansów,

${ }^{69}$ M. Banaś, Utworzenie Krajowej Administracji Skarbowej skuteczną reformą administracji skarbowej i celnej, [w:] Stulecie polskiej administracji. Doświadczenia i perspektywy, red. W. Federczyk, Warszawa 2018, s. 23 i n.

70 Zob. I. Nowak, National Revenue Administration...; idem, An officer employed as a revenue collector in the structure of the National Revenue Administration - critical remarks, „Prawo Budżetowe Państwa i Samorządu” 2020, nr 3, s. 83-113; S. Sękowski, Kontroler z konspiry, „Do Reczy” 2019, nr 33; https://celnicy.pl/threads/kontroler-zkonspiry.16183/ (dostęp: 16.07.2020).

71 Za interpelacją poselską nr 30349 J. Cichonia do Ministra Finansów w sprawie reformy administracji skarbowej, http://www.sejm.gov.pl/Sejm8.nsf/InterpelacjaTresc. xsp?key=BAPKA7 (dostęp: 15.09.2020).

72 Ibidem.

73 Pismo S. Siwego (Przewodniczącego Związku Zawodowego Celnicy PL) z dnia 2 czerwca 2017 r. skierowane do funkcjonariuszy, urzędników i pracowników Krajowej Administracji Skarbowej, http://solid.home.pl/kas/celnicypl.pdf (dostęp: 15.07.2020). 
jak i nowo utworzonej organizacji, jaką jest Krajowa Administracja Skarbowa, dalekie jest od szykan działaczy związkowych czy prób ograniczania działalności niezależnych związków zawodowych"74 (sic!).

„Ucywilnienie” funkcjonariuszy celnych, czyli przekształcenie ich stosunku służbowego $\mathrm{w}$ stosunek pracy, rozminęło się z interesem publicznym, było nietransparentne i naruszyło zasadę zaufania do państwa i stanowionego przez nie prawa ${ }^{75}$. Niezrozumienie i dezaprobatę budzi dodatkowo fakt, że przedstawianie propozycji „ucywilnienia” pod groźbą utraty zatrudnienia było sprzeczne $\mathrm{z}$ zasadą praworządności oraz zasadą ochrony stosunku służbowego funkcjonariuszy służby publicznej ${ }^{76}$. Również zdaniem Najwyższej Izby Kontroli „proces przekształcenia struktury organizacyjnej administracji celno-skarbowej nie został właściwie przygotowany i przeprowadzony, m.in. nie przeprowadzono analizy potrzeb kadrowych, a zastosowana praktyka wygaszania zatrudnienia budzi wątpliwości natury prawnej w zakresie przestrzegania i ochrony praw pracowniczych, głównie przez niewystarczający nadzór Szefa KAS nad procesem kształtowania polityki kadrowej"77. Warto też zwrócić uwagę, że w całym procesie legislacyjnym konsolidującym administrację danin publicznych, którego następstwem była destabilizacja zawodowa i prywatna kilku

74 Pismo Ministra Rozwoju i Finansów z lipca 2017 r., DLK2.054.17.2017, http://orka2. sejm.gov.pl/INT8.nsf/klucz/658C47F0/\%24FILE/i14196-o1.pdf (dostęp: 17.08.2020).

75 Szerzej A. Halicki, Petycja w sprawie przeprowadzenia przez Ministra Rozwoju i Finansów analizy SWOT, ewentualnie innej podobnej analizy dotyczacej planowanego przez Ministerstwo Finansów procesu ucywilnienia funkcjonariuszy Służby Celno-Skarbowej, Biała Podlaska, 22 kwietnia 2017 r., https://www.pomorskie.kas.gov.pl/documents/3555563/4805403/Petycja+-analiza+SWOT (dostęp: 11.08.2020); idem, Analiza projektu ustawy z dnia 31 maja 2016 r. - Przepisy wprowadzające ustawę o Krajowej Administracji Skarbowej, „Monitor Prawa Celnego i Podatkowego” 2016, nr 8, s. 292 i n.; W. Modzelewski, Opinia z dnia 16 sierpnia 2016 r. w zakresie oceny potencjalnych skutków wejścia w życie przepisów projektowanej ustawy o Krajowej Administracji Skarbowej, https://webcache.googleusercontent.com/search?q=cache:t_POa0ecztMJ; https://www.senat.gov.pl/ download/gfx/senat/pl/senatposiedzeniatematy/3176/drukisejmowe/826-001.pdf $+\& \mathrm{~cd}=$ $1 \& \mathrm{hl}=\mathrm{pl} \& \mathrm{ct}=\mathrm{clnk} \& \mathrm{gl}=\mathrm{pl} \& \mathrm{client}=$ firefox-b-d (dostęp: 2.07 .2020$)$.

76 E. Ura, „Ucywilnianie”..., s. 263.

77 Wystąpienie pokontrolne Najwyższej Izby Kontroli z dnia 21 grudnia 2018 r., nr KBF. 410.005.01.2018, https://www.google.com/search?hl=pl\&source=hp\&ei=X4CpX pGKBMKalwSkkI2gCQ\&q=KBF.+410.005.01.2018\&oq=KBF.+410.005.01.2018\&gs_lcp= CgZwc3ktYWIQDFD7DFj7DGDMEWgAcAB4AIABiAGIAeYBkgEDMS4xmAEAoAEC oAEBqgEHZ3dzLXdperABAA\&sclient=psy-ab\&ved=0ahUKEwjRtaqY3o3pAhVCzYU KHSRIA5QQ4dUDCAo (dostęp: 14.08.2020). 
tysięcy funkcjonariuszy celnych, brały udział osoby, którym podobno są bliskie wartości chrześcijańskie (a przynajmniej tak deklarują), zapominające jednocześnie o nauce płynącej z Pisma Świętego (Biblii), nolens volens Konstytucji Chrześcijan ${ }^{78}$, a dotyczącej miłości wobec bliźniego i nieczynienia mu krzywdy (sic!).

\section{BIBLIOGRAFIA}

Banaś M., Utworzenie Krajowej Administracji Skarbowej skuteczna reforma administracji skarbowej i celnej, [w:] Stulecie polskiej administracji. Doświadczenia i perspektywy, red. W. Federczyk, Warszawa 2018.

Bielecki L., Ustrojowe prawo administracyjne (podatkowe) dotyczące Krajowej Administracji Skarbowej jako przykład wplywu ideologii politycznej na kształt prawa, „Przegląd Prawa Publicznego" 2017, nr 7-8.

Biernat T., Między polityka a prawem. Problem „upolitycznienia” tworzenia prawa, przeglad prawa i administracji, „Przegląd Prawa i Administracji” 2017, nr 110.

Brzeziński B., Prawo podatkowe. Zagadnienia teorii i praktyki, Torun 2017.

Brzeziński B., Współczesne problemy organizacji i działania administracji podatkowej na świecie, „Kwartalnik Prawa Podatkowego” 2002, nr 2.

Brzeziński B., Nykiel W., Stan prawa podatkowego w Polsce. Raport 2010, „Kwartalnik Prawa Podatkowego" 2011, nr 1.

Byrzykowski W., Zdunek A., Ustawa o Krajowej Administracji Skarbowej - organy, zadania oraz forma ich realizacji, „Przegląd Podatkowy” 2017, nr 3.

Gajewski D., Nowak-Far A., Krajowa Administracja Skarbowa - propozycja konsolidacji aparatu skarbowego a uszczelnienie systemu podatkowego, „Analizy i Studia” 2016, nr 2.

Giełda M., Godność człowieka w otoczeniu administracji publicznej - wybrane zagadnienia, „Przegląd Prawa i Administracji” 2017, nr 111.

Gomułowicz A., Moralność podatkowa - uwarunkowania i zasadnicze dylematy, [w:] Ex iniuria non oritur ius. Księga pamiątkowa ku czci Profesora Wojciecha Łączkowskiego, red. A. Gomułowicz, J. Małecki, Poznań 2003.

Halicki A., Analiza projektu ustawy z dnia 31 maja 2016 r. - Przepisy wprowadzajace ustawę o Krajowej Administracji Skarbowej, „Monitor Prawa Celnego i Podatkowego” 2016, nr 8.

Halicki A., Petycja w sprawie przeprowadzenia przez Ministra Rozwoju i Finansów analizy SWOT, ewentualnie innej podobnej analizy dotyczacej planowanego przez Ministerstwo Finansów procesu ucywilnienia funkcjonariuszy Stużby Celno-Skarbowej, Biała Podlaska, 22 kwietnia 2017 r., https://www.pomorskie.kas.gov.pl/documents/ 3555563/4805403/Petycja+-analiza+SWOT.

78 Por. I. Nowak, Małżeństwo a związki partnerskie w świetle wybranych regulacji polskiego prawa podatkowego, „Kwartalnik Prawa Podatkowego” 2017, nr 3, s. 55-83. 
Jastrzębski B., Ustrojowe zasady demokratycznego państwa prawa (jako gwarancje ochrony praw obywatelskich), [w:] Prawne gwarancje ochrony praw jednostki wobec działań administracji publicznej, red. E. Ura, Rzeszów 2002.

Jastrzębski B., Wybrane zagadnienia sprawnego działania administracji publicznej, [w:] Administracja publiczna u progu XXI wieku. Prace dedykowane prof. $z w$. dr. hab. Janowi Szreniawskiemu z okazji Jubileuszu 45-lecia pracy naukowej, red. Z. Niewiadomski, J. Buczkowski, J. Łukasiewicz, J. Posłuszny, J. Stelmasiak, Przemyśl 2000.

Kaliński M., Rozwój zasobów ludzkich w administracji podatkowej, „Zarządzanie Zasobami Ludzkimi” 2011, nr 5.

Kosińska R., Ruśkowski E., Woltanowski P., Efektywność służb podatkowych w okresie ich reformowania - wybrane zagadnienia, „Finanse, Rynki Finansowe, Ubezpieczenia” 2016, nr 6.

Krajowa Administracja Skarbowa. Komentarz, red. A. Melezini, K. Teszner, Warszawa 2018.

Kulicki J., Koncepcja Krajowej Administracji Skarbowej w świetle problemów administracji danin publicznych $w$ Polsce, „Analizy i Studia” 2016, nr 2.

Laszuk M., Status prawny Stużby Celno-Skarbowej, „Przegląd Prawa Publicznego” 2018, nr 6.

Łączkowski W., O godziwe prawo, „Ethos” 2002, nr 1-2.

Łączkowski W., Prawo naturalne a prawo stanowione. Uwagi prawnika, „Ethos” 1999, nr $1-2$.

Łączkowski W., Wymiar sprawiedliwości a stosowanie prawa, [w:] Ius et lex. Ksiega pamiątkowa ku czci prof. Adama Strzembosza, red. A. Dębiński, A. Grześkowiak, K. Wiak, Lublin 2002.

Modzelewski W., Opinia z dnia 16 sierpnia 2016 r.w zakresie oceny potencjalnych skutków wejścia w życie przepisów projektowanej ustawy o Krajowej Administracji Skarbowej, https:// webcache.googleusercontent.com/search?q=cache:t_POa0ecztMJ; https://www.senat. gov.pl/download/gfx/senat/pl/senatposiedzeniatematy/3176/drukisejmowe/826-001. $\mathrm{pdf}+\& \mathrm{~cd}=1 \& \mathrm{hl}=\mathrm{pl} \& \mathrm{ct}=\mathrm{clnk} \& \mathrm{gl}=\mathrm{pl} \& \mathrm{client}=$ firefox $-\mathrm{b}-\mathrm{d}$.

Nowak I., An officer employed as a revenue collector in the structure of the National Revenue Administration - critical remarks, „Prawo Budżetowe Państwa i Samorządu” 2020, nr 3.

Nowak I., Krajowa Administracja Skarbowa w liczbach, „Kazus Podatkowy” 2020, nr 4.

Nowak I., Małżeństwo a związki partnerskie w świetle wybranych regulacji polskiego prawa podatkowego, „Kwartalnik Prawa Podatkowego” 2017, nr 3.

Nowak I., National Revenue Administration - current organisational and financial problems, „Prawo Budżetowe Państwa i Samorządu” 2020, nr 2.

Nowak I., Dominiak M., Krajowa Administracja Skarbowa a uszczelnianie systemu podatkowego - spostrzeżenia po dwóch latach funkcjonowania, [w:] Przestępczość gospodarcza. System zwalczania. Cz. I, red. P. Łabuz, I. Malinowska, M. Michalski, Warszawa 2020.

Nykiel W., Opinia z 2 lipca 2007 r. o projekcie ustawy o Krajowej Administracji Skarbowej, $\mathrm{nr}$ RL-0303-69/07, https://radalegislacyjna.gov.pl/dokumenty/opinia-z-2-lipca2007-r-o-projekcie-ustawy-o-krajowej-administracji-skarbowej. 
Piotrowski M., Ocena przeprowadzonej reformy związanej z utworzeniem Krajowej Administracji Skarbowej w świetle zasad tworzenia prawa i ochrony praw pracowniczych, listopad 2018.

Sękowski S., Kontroler z konspiry, „Do Reczy” 2019, nr 33.

System organów podatkowych w Polsce, red. P. Smoleń, Warszawa 2009.

Szpotański J., Gnom. Caryca. Szmaciak, Łomianki 2014.

Szwast M., Ocena przeprowadzonej reformy zwiazanej z utworzeniem Krajowej Administracji Skarbowej $w$ świetle zasad tworzenia prawa i ochrony praw pracowniczych, 15 września $2018 \mathrm{r}$.

Teszner K., Administracja podatkowa i kontrola skarbowa w Polsce, LEX/el. 2012.

Ura E., „Ucywilnianie” dotychczasowych stosunków służbowych funkcjonariuszy celnych $w$ związku z reforma administracji celno-skarbowej - w kontekście zasady praworząności, „Przegląd Prawa i Administracji” 2018, nr 114.

Ura E., Pieprzny S., Reforma administracji celno-skarbowej przyczyna wygaśnięcia stosunków zatrudnienia z mocy prawa pracowników i funkcjonariuszy tej administracji, [w:] Przemiany cywilizacyjne a funkcjonowanie administracji publicznej. Ksiega jubileuszowa dedykowana Profesorowi Bronisławowi Jastrzębskiemu w dziewięćdziesiąta rocznice urodzin, red. J. Strzelecki, Płock 2017.

Ustawa o Krajowej Administracji Skarbowej. Komentarz, red. L. Bielecki, A. Gorgol, Warszawa 2018.

Żaczkiewicz-Zborska K., W 2018 r. więcej ustaw, ale złej jakości i pisanych w pośpiechu, https:// www.prawo.pl/prawo/jakosc-prawa-tworzonego-w-polsce-w-2018-roku,351131.html.

\section{Customs officials in the structure of the National Revenue AdMINISTRATION - SELECTED COMMENTS}

Summary. The paper is mainly devoted to the subject-matter of the so-called "turning customs officials into civilians", that it transforming their service relationships into employment relationships in the framework of consolidation of tax, revenue and customs administration into the National Revenue Administration. The author has shown that the reform of public levies administration - without a doubt necessary after close to 30 years of status quo - has, nevertheless, led to a few thousand reductions of employment of customs officials by terminating their service relationships or transforming them into employment relationships. Moreover, the author shows in the publication that as a result of legislator's conscious operation a "base law" was adopted which constitutes violation of the principle of trust in the state and in the law given by it.

Keywords: National Revenue Administration, customs official, service relationship, employment relationship, public levies administration 